\title{
Evaluasi Karakter Kualitatif dan Kuantitatif Cabai Hias (Capsicum annuum L.) IPB
}

\author{
Evaluation of Qualitative and Quantitative Character \\ of IPB Ornamental Chili Pepper (Capsicum annuum L.)
}

\author{
Kana Dau Sukmawati ${ }^{1}$, Muhamad Syukur ${ }^{12^{*}}$, Arya Widura Ritonga ${ }^{12}$ \\ ${ }^{1}$ Departemen Agronomi dan Hortikultura, Fakultas Pertanian Institut Pertanian Bogor \\ Jl. Meranti Kampus IPB Darmaga, Bogor, Indonesia \\ ${ }^{2}$ Pusat Kajian Hortikultura Tropika (PKHT) Institut Pertanian Bogor, Kampus IPB Baranangsiang \\ Jl. Raya Pajajaran Bogor, Indonesia
}

Diterima 28 Januari 2019/Disetujui 22 Februari 2019

\begin{abstract}
Chili pepper (Capsicum annuum L.) is a commodity that has a high economic value and has been known and cultivated by people throughout the world. Ornamental chili pepper has aesthetic value as ornamental plants such as the round or long round fruits and the diversity of fruit colors. This study was conducted to evaluate the qualitative and quantitative characters of 11 genotypes of ornamental chili pepper to obtain superior ornamental chili pepper varieties. The analyzed variables were the plant height, stem length, stem diameter, stem color, shortened internode, plant habitus, leaf shape, leaf color, leaf length, leaf width, days to flowering, corolla color, anther color, flower position, harvest date, fruit weight, fruit length, fruit pedicel length, fruit diameter, fruit shape, fruit shape at blossom end, fruit color, and anthocyanin coloration. This study was conducted in green house of the Cikabayan Experimental Garden and the Laboratory of Genetics and Plant Breeding, Department of Agronomy and Horticulture, Faculty of Agriculture, Bogor Agricultural University, from January to June 2018. The experimental design was randomized complete block design with one factor (genotipe) and four replicates. All genotypes evaluated had diverse quantitative and qualitative characters especially in the character of fruit weight, fruit length, and fruit color. The most preferred genotypes were Ayesha 1, Violeta, and Nazla. Ayesha 1 was favored because of its rounded fruit, interesting and quite varied fruit colors. Violeta and Nazla were prefered because of the purple fruits. Nazla was prefered as pot ornamental plants for its short plant and the convenience to take care.
\end{abstract}

Keywords: Ayesha1, fruit color, Nazla, rounded fruit, Violeta

\section{ABSTRACT}

Cabai (Capsicum annuum L.) merupakan komoditas yang memiliki nilai ekonomi tinggi dan merupakan tanaman yang sudah dikenal dan dibudidayakan oleh masyarakat di seluruh dunia. Karakter cabai hias memiliki nilai estetika sebagai tanaman hias seperti bentuk buah yang umumnya bulat atau bulat panjang dan warna buah yang sangat bervariasi. Penelitian ini dilakukan untuk mengevaluasi karakter kualitatif dan kuantitatif 11 genotipe cabai hias untuk menghasilkan varietas cabai hias yang unggul. Karakter yang diamati terdiri atas tinggi tanaman, tinggi dikotomus, diameter batang, warna batang, pemendekan ruas, habitus tanaman, bentuk daun, warna daun, panjang daun, lebar daun, waktu munculnya bunga, warna mahkota bunga, warna anther, kedudukan bunga, umur panen buah, bobot buah, panjang buah, panjang tangkai buah, diameter buah, bentuk buah, bentuk pangkal buah, perubahan warna buah, dan pewarnaan antosianin. Penelitian dilakukan di rumah kaca Kebun Percobaan Cikabayan dan Laboratorium Genetika dan Pemuliaan Tanaman, Departemen Agronomi dan Hortikultura, Fakultas Pertanian Institut Pertanian Bogor. Penelitian dilaksanakan pada bulan Januari sampai Juni 2018. Rancangan penelitian yang digunakan adalah Rancangan Kelompok Lengkap Teracak (RKLT) satu faktor yaitu genotipe dengan 4 kali ulangan. Semua genotipe yang dievalusi memiliki karakter kuantitatif dan kualitatif yang beragam baik antar genotipe uji maupun dengan varietas pembanding, terutama pada karakter bobot buah, panjang buah, dan warna buah. Genotipe yang paling disukai adalah Ayesha 1, Violeta, dan Nazla. Ayesha 1 disukai karena bentuk buahnya yang membulat dan warna buahnya yang menarik dan beragam. Violeta dan Nazla disukai karena buahnya berwarna ungu. Nazla lebih disukai untuk tanaman hias pot karena perawakannya yang pendek dan memudahkan perawatan.

Kata kunci: Ayesha 1, buah membulat, Nazla, Violeta, warna buah

\footnotetext{
* Penulis untuk korespondensi. e-mail: muhsyukur@ipb.ac.id
} 


\section{PENDAHULUAN}

Cabai (Capsicum annuum L.) merupakan tanaman yang sudah dikenal oleh masyarakat di seluruh dunia terutama buahnya yang dimanfaatkan untuk menghasilkan rasa pedas pada masakan. Tanaman cabai merupakan tanaman yang mudah tumbuh di berbagai tempat sehingga sudah berhasil dibudidayakan dan dikembangkan secara luas di India, Sri Lanka, Malaysia, Indonesia, Amerika Tengah, Amerika Selatan, Afrika Utara, serta Hawai walaupun pada awalnya hanya dikembangkan oleh negara-negara di Eropa. Tanaman cabai di Indonesia dapat ditemukan di seluruh wilayah dari Sabang sampai Merauke (Harpenas dan Dermawan, 2010). C. annuum merupakan jenis cabai yang paling beragan dan paling banyak dibudidayakan, terdiri atas berbagai varietas cabai termasuk paprika dan jalapeno (Lannes et al., 2007).

Cabai merupakan komoditas yang memiliki nilai ekonomi tinggi yang dibuktikan dengan harga yang sering berfluktuasi setiap tahunnya. Fluktuasi harga cabai dilihat sebagai peluang sehingga banyak pihak berusaha membudidayakan tanaman cabai, baik skala rumah tangga maupun skala komersial. Budidaya cabai skala rumah tangga mulai banyak dilakukan dengan menanam dalam pot. Bertanam cabai dalam pot kemudian semakin berkembang bukan hanya untuk memenuhi kebutuhan cabai rumah tangga, tetapi juga dengan pertimbangan hobi sebagai tanaman hias yang memungkinkan untuk dikomersialkan (Setiadi, 2011). Menanam cabai hias dalam pot memiliki kelebihan tidak memerlukan lahan yang luas, perbanyakan benih mudah, berumur pendek, dan tahan terhadap cekaman kekeringan. Beberapa varietas cabai yang ada sekarang merupakan cabai yang secara khusus dikembangkan oleh pemulia tanaman sebagai tanaman hias, namun varietas cabai hias tersebut belum dikenal secara luas oleh masyarakat. Cabai hias dapat dikonsumsi segar maupun sebagai tanaman hias pekarangan sehingga sangat berpotensi untuk dikomersialkan dengan harga yang lebih tinggi (Ari et al., 2006).

Galur cabai hias IPB berpotensi untuk dikembangkan sebagai varietas baru untuk mendapatkan tanaman $d w a r f$, buah membulat, buah memanjang, ada pemendekan ruas, buah lebat, buah banyak warna dalam satu tanaman, dan buah berwarna ungu (Sulassih et al., 2017). Evaluasi karakter kualitatif dan kuantitatif dilakukan terhadap F5 hasil persilangan Syakira dan IPB C320 yang diharapkan memiliki karakter yang berbeda dengan varietas Namira, Lembayung, dan Ayesha. Ayesha merupakan cabai hias dengan karakter ukuran tanaman dwarf, buah membulat, buah lebat, dan banyak warna dalam satu tanaman. Namira adalah cabai hias dengan ukuran tanaman dwarf, buah memanjang, ada pemendekan ruas, buah lebat, dan banyak warna dalam satu tanaman. Lembayung merupakan cabai hias dengan ukuran tanaman $d$ warf, buah memanjang, buah lebat, dan berwarna ungu dalam satu tanaman (Sulassih et al., 2017).

Cabai hias memiliki karakter tertentu sebagai tanaman hias seperti bentuk buah yang umumnya bulat atau bulat panjang dan warna buah yang sangat bervariasi, seperti merah, merah muda, kuning, ungu, dan coklat. Variasi warna buah pada satu tanaman dapat menambah nilai estetika tanaman cabai hias. Perbedaan warna buah cabai tersebut disebabkan oleh perbedaan waktu munculnya bunga yang akan berpengaruh pada perbedaan tingkat kematangan buah, sehingga akan terdapat buah yang berwarna-warni. Varietas Namira, Lembayung, dan Ayesha memiliki warna buah yang berbeda pada buah muda, buah intermediet, dan buah matang (Lestari, 2017).

Karakter yang digunakan sebagai kriteria seleksi cabai menurut Syukur et al. (2010) adalah jumlah buah per tanaman, bobot buah, diameter pangkal, dan diameter tengah buah. Cabai hias umumnya hanya ditanam di pot-pot bunga atau polibag sebagai hiasan di pekarangan rumah. Karakter cabai hias dengan panjang dan diameter buah kecil biasanya lebih disukai konsumen (Silva et al., 2015). Kegiatan pemuliaan terhadap cabai hias masih perlu dilakukan untuk merakit varietas cabai hias yang memiliki karakter-karakter yang menarik yang dapat dijadikan varietas budidaya. Penelitian ini bertujuan mengevaluasi karakter kualitatif dan kuantitatif sebelas genotipe cabai hias untuk menghasilkan varietas cabai hias yang unggul.

\section{BAHAN DAN METODE}

Penelitian dilakukan di rumah kaca Kebun Percobaan Cikabayan dan Laboratorium Genetika dan Pemuliaan Tanaman, Departemen Agronomi dan Hortikultura, Fakultas Pertanian Institut Pertanian Bogor. Penelitian dilaksanakan pada bulan Januari sampai Juni 2018. Bahan yang digunakan dalam penelitian adalah 11 genotipe cabai hias IPB, yaitu Ayesha 1, Viola-0, Violeta, Nazla, F5 Syakira x 320-2011-1, F5 Syakira x 320-201-1-2, F5 Syakira x 320-201-2-1, F5 Syakira x 320-202-1-1, F5 Syakira x 320-202-2-1, F5 Syakira x 320-202-2-2, dan F5 Syakira x 320-2022-3 (Viola) dengan 3 varietas pembanding yaitu Namira, Lembayung, dan Ayesha. Media tanam yang digunakan adalah campuran pupuk kandang, arang sekam, dan cocopeat dengan perbandingan 1:1:1, pupuk AB Mix daun, pupuk AB Mix buah, dan insektisida. Alat yang digunakan adalah tray semai, pot dengan diameter $18 \mathrm{~cm}$, ajir bambu, tali rafia, label, jangka sorong, penggaris, timbangan digital, kamera, dan alat pertanian konvensional.

Rancangan percobaan yang digunakan adalah Rancangan Kelompok Lengkap Teracak (RKLT) satu faktor yaitu genotipe dengan 4 kali ulangan. Pengujian dilakukan terhadap 11 genotipe cabai hias dengan 3 varietas pembanding (Namira, Lembayung, dan Ayesha), sehingga terdapat 56 satuan percobaan. Masing-masing satuan percobaan terdiri dari 10 tanaman sehingga jumlah keseluruhan tanaman sebanyak 560 tanaman.

Pelaksanaan percobaan diawali dengan menyemai benih pada tray semai sebanyak 1 benih per lubang tray. Pupuk AB Mix daun mulai diberikan 2 minggu setelah bibit tumbuh dengan dosis $5 \mathrm{ml} \mathrm{L}^{-1}$, satu kali per minggu. Pemupukan ditingkatkan ketika daun mulai menguning hingga daun berwarna hijau kembali, yaitu setelah dilakukan pemupukan 2 hari sekali dengan dosis yang sama. Penyulaman dilakukan mulai 10 hari setelah semai hingga 
jumlah bibit mencukupi kebutuhan percobaan. Pindah tanaman dilakukan 50 hari setelah semai. Sebagian bibit varietas Lembayung dan genotipe F5 Syakira x 320-2011-2 masih terlalu kecil untuk dipindah tanam sehingga baru dipindahkan 19 hari setelah pindah tanam pertama.

Pemeliharaan tanaman yang dilakukan meliputi penyiangan gulma, penyiraman, pemupukan, dan penyemprotan insektisida. Pemupukan $\mathrm{AB}$ Mix daun dilakukan dua kali per minggu dengan dosis $5 \mathrm{ml} \mathrm{L}^{-1}$ sampai tanaman berbuah kemudian dilanjutkan dengan pemupukan AB Mix buah dengan dosis yang sama. Insektisida yang digunakan adalah Agrimec 18EC dan Meothrin 50EC dengan dosis $0.5 \mathrm{ml} \mathrm{L}^{-1}$. Penyemprotan dilakukan satu kali per minggu, kemudian ketika serangan hama sudah cukup parah ditingkatkan menjadi dua kali per minggu.

Pengamatan dilakukan terhadap semua genotipe yang diuji dan varietas pembanding. Karakter yang diamati adalah karakter kualitatif dan kuantitatif berdasarkan panduan International Plant Genetic Resources Institute (IPGRI) (1995) dan buku Calibration Books Capsicum annum L., Sweet Pepper, Hot Pepper, Paprika, Chili. Version 1 oleh Naktuinbouw (2010). Karakter yang diamati terdiri atas tinggi tanaman, tinggi dikotomus, bentuk batang, diameter batang, warna batang, pemendekan ruas, habitus tanaman, bentuk daun, warna daun, panjang daun, lebar daun, permukaan daun, tepi daun, ujung daun, waktu munculnya bunga, warna mahkota bunga, warna anther, kedudukan bunga, umur panen buah, bobot buah, panjang buah, panjang tangkai buah, diameter buah, bentuk buah, bentuk pangkal buah, penampang melintang buah, perubahan warna buah, dan pewarnaan antosianin.

Data kualitatif hasil pengamatan karakter morfologi disajikan secara deskriptif. Data kuantitatif dianalisis menggunakan uji F. Jika perlakuan berpengaruh nyata maka dilanjutkan menggunakan uji lanjut Duncan Multiple Range Test (DMRT) pada taraf 5\%. Uji preferensi konsumen dilakukan menggunakan metode survei secara langsung kepada partisipan menggunakan kuesioner. Survei dilaksanakan untuk mengetahui tingkat kesukaan konsumen terhadap genotipe tertentu berdasarkan karakter-karakter yang dimiliki oleh genotipe tersebut.

\section{HASIL DAN PEMBAHASAN}

\section{Karakter Kuantitatif Rekapitulasi F Hitung, Peluang, dan Koefisien Keragaman}

Hasil analisis ragam (Tabel 1) menunjukkan perbedaan yang nyata antar genotipe yang diuji pada semua karakter kuantitatif yang diamati. Hal ini tentunya diharapkan sebagai hasil eveluasi genotipe cabai hias untuk memiliki keragaman pada setiap karakter yang diamati. Koefisien keragaman pada seluruh karakter kuantitatif yang diamati berkisar antara $6.21 \%-20.86 \%$.

\section{Tinggi Tanaman, Tinggi Dikotomus, Diameter Batang}

Tinggi tanaman genotipe uji berkisar antara 15.63$41.48 \mathrm{~cm}$. Sementara itu, tinggi tanaman verietas pembanding berkisar antara 19.33-28.61 cm. Genotipe terpendek adalah Nazla yang memiliki tinggi tanaman setara dengan varietas Namira. Sedangkan tanaman yang lebih tinggi dari varietas pembanding adalah genotipe Ayesha 1, Viola-0, Violeta, F5 Syakira x 320-202-2-2. Tinggi dikotomus genotipe uji berkisar antara 7.33-16.52 cm, sementara tinggi dikotomus varietas pembanding berkisar 9.26-11.42 cm. Tinggi dikotomus genotipe uji setara dengan tinggi dikotomus varietas pembanding, kecuali pada genotipe Ayesha 1, Viola-0, Violeta, F5 Syakira x 320-202-2-2 (Tabel 2). Berdasarkan uji preferensi konsumen, tanaman yang pendek seperti Nazla lebih disukai karena lebih cocok untuk ditanaman di pot sebagai tanaman hias.

Tinggi tanaman maupun tinggi dikotomus genotipe F5 Syakira x 320-202-2-2 kurang sesuai dengan ukuran dan bobot buahnya yang besar. Tanaman yang memiliki ukuran buah yang panjang dan menggantung ke bawah

Tabel 1. Rekapitulasi F hitung, peluang, dan koefisien keragaman

\begin{tabular}{clccr}
\hline No & \multicolumn{1}{c}{ Karakter } & F Hitung & Peluang & Koefisien Keragaman $(\%)$ \\
\hline 1 & Tinggi tanaman & $37.56^{* *}$ & $<.0001$ & 9.68 \\
2 & Tinggi dikotomus & $14.82^{* *}$ & $<.0001$ & 14.67 \\
3 & Diameter batang & $13.13^{* *}$ & $<.0001$ & 9.23 \\
4 & Panjang daun & $2.41^{*}$ & 0.018 & 20.86 \\
5 & Lebar daun & $2.52^{*}$ & 0.014 & 17.98 \\
6 & Bobot buah & $67.66^{* *}$ & $<.0001$ & 13.09 \\
7 & Panjang buah & $85.34^{* *}$ & $<.0001$ & 9.25 \\
8 & Panjang tangkai buah & $13.80^{* *}$ & $<.0001$ & 7.38 \\
9 & Diameter buah & $24.97^{* *}$ & $<.0001$ & 7.00 \\
10 & Umur berbunga & $19.00^{* *}$ & $<.0001$ & 6.21 \\
11 & Umur panen & $6.55^{* *}$ & $<.0001$ & 9.16 \\
\hline
\end{tabular}

Keterangan: $* *=$ sangat nyata pada taraf $5 \%$ berdasarkan uji $\mathrm{F}, *=$ nyata pada taraf $5 \%$ berdasarkan uji $\mathrm{F}$. 
seperti genotipe F5 Syakira x 320-202-2-2, lebih cocok dengan batang yang tinggi seperti tanaman cabai komersial. Rommahdi et al. (2015) menyatakan karakter tinggi tanaman dan tinggi dikotomus berpengaruh terhadap posisi atau letak buah terhadap permukaan tanah. Dikotomus yang pendek menyebabkan buah terlalu dekat dengan media tanam dan sering terkena percikan air.

Diameter batang genotipe uji berkisar antara 0.29-0.47 $\mathrm{cm}$, sementara itu diameter batang varietas pembanding berkisar antara $0.24-0.36 \mathrm{~cm}$. Diameter batang genotipe Viola-0 lebih besar dari varietas pembanding, sedangkan diameter batang genotipe F5 Syakira x 320-202-1-1 merupakan yang paling kecil dan setara dengan varietas Namira dan Lembayung (Tabel 2). Diameter batang genotipe F5 Syakira x 320- 202-2-2 termasuk cukup besar dibanding dengan genotipe uji lainnya, namun diameter batang tersebut belum cukup besar untuk dapat menopang bobot buah yang besar, sehingga beberapa tanaman tidak dapat berdiri tegak walaupun sudah dibantu dengan ajir.

Panjang Daun, Lebar Daun, Umur Berbunga, dan Umur Panen

Panjang daun genotipe berkisar antara $2.94-5.29 \mathrm{~cm}$, sementara panjang daun varietas pembanding berkisar antara 3.20-4.28 cm (Tabel 3). Lebar daun genotipe uji berkisar antara $1.36-2.13 \mathrm{~cm}$, sementara lebar daun variets pembanding 1.41-1.90 cm. Panjang dan lebar daun semua genotipe uji setara dengan panjang dan lebar daun varietas pembanding. Genotipe F5 Syakira x 320-202-2-2 memiliki daun yang paling besar diantara genotipe uji dan masih setara dengan ukuran daun varietas Namira. Genotipe yang memiliki daun terkecil adalah Ayesha 1 dan Viola-0.
Genotipe uji berbunga dalam rentang 16-25 hari setelah tanam (HST). Sementara varietas pembanding berbunga antara 18-24 HST. Genotipe dengan umur berbunga tercepat adalah Ayesha 1 (16 HST) lebih cepat dari varietas pembanding, sedangkan yang paling lama berbunga adalah F5 Syakira x 320-201-1-1 dan F5 Syakira x 320-201-1-2 (25 HST) setara dengan varietas Lembayung. Beberapa tanaman genotipe Ayesha 1 sudah mulai berbunga ketika masih dalam persemaian.

Umur panen genotipe uji berkisar antara 67-99 HST, sedangkan umur panen varietas pembanding berkisar antara 67-76 HST. Gentoipe F5 Syakira x 320-201-1-1 dan F5 Syakira x 320-201-1-2 mencapai umur panen lebih lama dari varietas pembanding, sedangkan genotipe lainnya memiliki umur panen yang setara dengan varietas pembanding.

\section{Bobot Buah, Panjang Buah, Panjang Tangkai Buah, dan Diameter Buah}

Bobot buah genotipe uji berkisar antara 1.02-3.63 g, sedangkan bobot buah varietas pembanding berkisar antara 0.41-0.87 g. Bobot buah genotipe Viola-0, Violeta, dan F5 Syakira x 320-202-2-1 setara dengan bobot buah varietas pembanding. Sedangkan genotipe lainnya memiliki bobot buah yang lebih besar dari varietas pembanding.

Panjang buah genotipe uji berkisar antara 2.12-7.42 $\mathrm{cm}$, sedangkan panjang buah verietas pembanding berkisar antara 1.83-2.50 cm. Panjang buah genotipe F5 Syakira $\mathrm{x}$ 320-202-2-2, Viola, F5 Syakira x 320- 201-1-1, dan Nazla lebih panjang dari varietas pembanding. Genotipe uji dengan panjang buah paling kecil adalah Ayesha 1 yang setara dengan varietas Ayesha. Diameter buah genotipe uji berkisar antara $0.84-1.22 \mathrm{~cm}$, sementara diameter buah

Tabel 2. Nilai tengah tinggi tanaman, tinggi dikotomus, dan diameter batang pada setiap genotipe

\begin{tabular}{|c|c|c|c|}
\hline Genotipe & Tinggi tanaman $(\mathrm{cm})$ & Tinggi dikotomus (cm) & Diameter batang $(\mathrm{cm})$ \\
\hline Ayesha 1 & $33.63 \mathrm{bc}$ & $16.52 \mathrm{a}$ & $0.40 \mathrm{~b}$ \\
\hline Viola-0 & $41.48 \mathrm{a}$ & $16.25 \mathrm{a}$ & $0.47 \mathrm{a}$ \\
\hline Violeta & $34.65 \mathrm{bc}$ & $15.06 \mathrm{a}$ & $0.39 \mathrm{bc}$ \\
\hline Nazla & $15.63 \mathrm{~g}$ & $8.18 \mathrm{e}$ & 0.33 cde \\
\hline F5 Syakira x 320-201-1-1 & $23.46 \mathrm{e}$ & $10.11 \mathrm{cde}$ & 0.34 cde \\
\hline F5 Syakira x 320-201-1-2 & $17.35 \mathrm{fg}$ & $7.67 \mathrm{e}$ & $0.35 \mathrm{~cd}$ \\
\hline F5 Syakira x 320-201-2-1 & $18.55 \mathrm{fg}$ & $8.30 \mathrm{e}$ & $0.36 \mathrm{bcd}$ \\
\hline F5 Syakira x 320-202-1-1 & 20.63 ef & $7.33 \mathrm{e}$ & $0.29 \mathrm{ef}$ \\
\hline F5 Syakira x 320-202-2-1 & $30.90 \mathrm{~cd}$ & $12.39 \mathrm{bc}$ & $0.38 \mathrm{bcd}$ \\
\hline F5 Syakira x 320-202-2-2 & $35.06 \mathrm{~b}$ & $14.50 \mathrm{ab}$ & $0.41 \mathrm{~b}$ \\
\hline F5 Syakira x 320-202-2-3 (Viola) & $19.88 \mathrm{ef}$ & $9.36 \mathrm{de}$ & $0.33 \mathrm{de}$ \\
\hline Namira & $19.33 \mathrm{fg}$ & $9.26 \mathrm{de}$ & $0.24 \mathrm{f}$ \\
\hline Lembayung & $27.26 \mathrm{~d}$ & $11.42 \mathrm{~cd}$ & $0.25 \mathrm{f}$ \\
\hline Ayesha & $28.61 \mathrm{~d}$ & $9.91 \mathrm{cde}$ & $0.36 \mathrm{bcd}$ \\
\hline
\end{tabular}

Keterangan : angka yang diikuti huruf yang sama pada kolom yang sama menunjukkan hasil yang tidak berberda nyata menurut uji DMRT 5\%. 
verietas pembanding berkisar antara $0.54-0.89 \mathrm{~cm}$. Diameter buah genotipe Violeta, Nazla, dan F5 Syakira x 320- 201-1-1 setara dengan varietas Ayesha, sedangkan genotipe lainnya lebih besar dari varietas pembanding. Konsumen cabai hias tertarik dengan bentuk buah yang membulat sehingga genotipe dengan ukuran buah pendek dan diameter buah yang besar seperti genotipe Ayesha 1 lebih disukai.
Panjang tangkai buah genotipe uji berkisar antara $1.73-2.54 \mathrm{~cm}$. Sementara panjang tangkai buah verietas pembanding berkisar antara 1.54-1.91 cm. Tangkai buah genotipe Violeta, Nazla, F5 Syakira x 320-201-2-1, F5 Syakira x 320-202-2-1, dan F5 Syakira x 320-202-2-2 lebih panjang dari tangkai buah verietas pembanding (Tabel 4). Buah merupakan salah satu bagian tanaman yang menjadi

Tabel 3. Nilai tengah panjang daun, lebar daun, umur berbunga, dan umur panen pada setiap genotipe

\begin{tabular}{lcccc}
\hline \multicolumn{1}{c}{ Genotipe } & Panjang daun $(\mathrm{cm})$ & Lebar daun $(\mathrm{cm})$ & Umur berbunga (HST) & Umur panen (HST) \\
\hline Ayesha 1 & $2.94 \mathrm{c}$ & $1.38 \mathrm{~cd}$ & $16 \mathrm{f}$ & $67 \mathrm{~cd}$ \\
Viola-0 & $2.95 \mathrm{c}$ & $1.36 \mathrm{~d}$ & $18 \mathrm{e}$ & $70 \mathrm{~cd}$ \\
Violeta & $3.74 \mathrm{bc}$ & $1.80 \mathrm{abcd}$ & $22 \mathrm{~cd}$ & $74 \mathrm{~cd}$ \\
Nazla & $4.04 \mathrm{abc}$ & $1.79 \mathrm{abcd}$ & $23 \mathrm{abcd}$ & $99 \mathrm{a}$ \\
F5 Syakira x 320-201-1-1 & $3.51 \mathrm{bc}$ & $1.71 \mathrm{abcd}$ & $25 \mathrm{a}$ & $89 \mathrm{ab}$ \\
F5 Syakira x 320-201-1-2 & $3.93 \mathrm{bc}$ & $2.06 \mathrm{a}$ & $25 \mathrm{a}$ & $79 \mathrm{bc}$ \\
F5 Syakira x 320-201-2-1 & $3.93 \mathrm{bc}$ & $1.93 \mathrm{ab}$ & $24 \mathrm{abc}$ & $75 \mathrm{~cd}$ \\
F5 Syakira x 320-202-1-1 & $4.27 \mathrm{abc}$ & $1.83 \mathrm{abcd}$ & $21 \mathrm{~d}$ & $68 \mathrm{~cd}$ \\
F5 Syakira x 320-202-2-1 & $4.41 \mathrm{ab}$ & $1.91 \mathrm{abc}$ & $19 \mathrm{e}$ & $69 \mathrm{~cd}$ \\
F5 Syakira x 320-202-2-2 & $5.29 \mathrm{a}$ & $2.13 \mathrm{a}$ & $19 \mathrm{e}$ & $69 \mathrm{~cd}$ \\
F5 Syakira x 320-202-2-3 (Viola) & $3.94 \mathrm{bc}$ & $1.81 \mathrm{abcd}$ & $19 \mathrm{e}$ & $67 \mathrm{~d}$ \\
Namira & $4.28 \mathrm{abc}$ & $1.90 \mathrm{abc}$ & $23 \mathrm{bcd}$ & $76 \mathrm{~cd}$ \\
Lembayung & $3.20 \mathrm{bc}$ & $1.41 \mathrm{bcd}$ & $24 \mathrm{ab}$ & $18 \mathrm{e}$ \\
Ayesha & $3.62 \mathrm{bc}$ & $1.47 \mathrm{bcd}$ & $68 \mathrm{~cd}$ \\
\hline
\end{tabular}

Keterangan : angka yang diikuti huruf yang sama pada kolom yang sama menunjukkan hasil yang tidak berberda nyata menurut uji DMRT 5\%.

Tabel 4. Nilai tengah bobot buah, panjang buah, diameter buah, dan panjang tangkai buah pada setiap genotipe

\begin{tabular}{|c|c|c|c|c|}
\hline Genotipe & Bobot buah (g) & Panjang buah $(\mathrm{cm})$ & Diameter buah $(\mathrm{cm})$ & Panjang tangkai $(\mathrm{cm})$ \\
\hline Ayesha 1 & 1.34 bcde & $2.12 \mathrm{fg}$ & $1.22 \mathrm{a}$ & $1.73 \mathrm{de}$ \\
\hline Viola-0 & $1.02 \mathrm{fgh}$ & $2.47 \mathrm{def}$ & $1.00 \mathrm{bc}$ & $1.95 \mathrm{~cd}$ \\
\hline Violeta & $1.09 \mathrm{efg}$ & $2.83 \mathrm{cde}$ & $0.88 \mathrm{~d}$ & $2.30 \mathrm{~b}$ \\
\hline Nazla & $1.24 \mathrm{def}$ & $3.13 \mathrm{c}$ & $0.90 \mathrm{~cd}$ & $2.21 \mathrm{~b}$ \\
\hline F5 Syakira x 320-201-1-1 & $1.27 \mathrm{cdef}$ & $3.30 \mathrm{bc}$ & $0.84 \mathrm{~d}$ & $1.81 \mathrm{~d}$ \\
\hline F5 Syakira x 320-201-1-2 & $1.26 \mathrm{cdef}$ & $2.61 \mathrm{def}$ & $1.00 \mathrm{bc}$ & $1.89 \mathrm{~cd}$ \\
\hline F5 Syakira x 320-201-2-1 & $1.58 \mathrm{~b}$ & 2.82 cde & $1.10 \mathrm{~b}$ & $2.27 \mathrm{~b}$ \\
\hline F5 Syakira x 320-202-1-1 & $1.43 \mathrm{bcd}$ & $2.95 \mathrm{~cd}$ & $1.07 \mathrm{~b}$ & $2.11 \mathrm{bc}$ \\
\hline F5 Syakira x 320-202-2-1 & $1.14 \mathrm{defg}$ & 2.89 cde & $1.07 \mathrm{~b}$ & $2.24 \mathrm{~b}$ \\
\hline F5 Syakira x 320-202-2-2 & $3.63 \mathrm{a}$ & $7.42 \mathrm{a}$ & $1.09 \mathrm{~b}$ & $2.54 \mathrm{a}$ \\
\hline F5 Syakira x 320-202-2-3 (Viola) & $1.56 \mathrm{bc}$ & $3.68 \mathrm{~b}$ & $1.04 \mathrm{~b}$ & $1.85 \mathrm{~cd}$ \\
\hline Namira & $0.87 \mathrm{gh}$ & 2.39 ef & $0.72 \mathrm{e}$ & $1.91 \mathrm{~cd}$ \\
\hline Lembayung & $0.41 \mathrm{i}$ & $2.50 \mathrm{def}$ & $0.54 \mathrm{f}$ & $1.75 \mathrm{de}$ \\
\hline Ayesha & $0.77 \mathrm{~h}$ & $1.83 \mathrm{~g}$ & $0.89 \mathrm{~d}$ & $1.54 \mathrm{e}$ \\
\hline
\end{tabular}

Keterangan : angka yang diikuti huruf yang sama pada kolom yang sama menunjukkan hasil yang tidak berberda nyata menurut uji DMRT 5\%. 
daya tarik pada cabai hias sehingga adanya keragaman ukuran buah pada genotipe uji akan menguntungkan. Hasil pengamatan kualitatif seperti warna dan bentuk buah juga menunjukkan adanya keragaman terutama pada perubahan warna dari buah muda hingga matang (Tabel 7). Karakter tinggi tanaman, diameter batang, bobot buah, dan diameter buah merupakan penyumbang keragaman genetik terbesar sehingga keragaman pada karakter-karakter tersebut merupakan poin penting dalam seleksi atau evaluasi genotipe cabai hias (Santos Pessoa et al., 2018).

\section{Evaluasi Karakter Kualitatif}

Karakter tinggi dikotomus dapat menunjukkan habitus. Menurut Rommahdi et al. (2015) karakter tinggi dikotomus berkaitan dengan habitus tanaman. Tinggi dikotomus genotipe Ayesha 1, Viola-0, dan Violeta saling tidak berbeda nyata (Tabel 2) dan ketiganya berhabitus tegak (Tabel 5). Genotipe Nazla, F5 Syakira x 320-201-1-2, F5 Syakira x 320-201-2-1, dan F5 Syakira x 320-202-1-1 juga menunjukkan tinggi dikotomus yang saling tidak berbeda nyata dan dengan habitus yang sama yaitu berbentuk intermediate (Tabel 5).

Genotipe Ayesha 1, Viola-0, Violeta, dan F5 Syakira X 320-202-2-2 berhabitus tegak sedangkan genotipe lainnya berhabitus intermediate termasuk ketiga varietas pembanding. Pemendekan ruas hanya ditemukan pada varietas Namira (Tabel 5). Warna batang yang diamati terdiri atas warna hijau, ungu, dan ungu-hijau. Warna hijau batang berdasarkan RHS Color Chart adalah hijau 143-C dan warna ungu adalah ungu N186-A. Warna batang ungu hanya dimiliki oleh varietas Lembayung. Genotipe Violeta, Nazla, dan F5 Syakira X 320-202-2-2 memiliki batang berwarna dominan ungu di bawah dikotomus, sedangkan diatas dikotomus berwarna hijau dengan warna ungu hanya pada sudut batang atau cabang yang berbentuk kotak atau persegi (Tabel 5).

Warna mahkota yang diamati sangat beragam berdasarkan pengamatan menggunakan RHS Color Chart (Tabel 6). Secara umum, warna mahkota bunga genotipe uji adalah putih, ungu, atau perpaduan putih dan ungu. Semua genotipe dengan mahkota bunga berwarna putih memiliki tipe warna putih yang berbeda dengan mahkota Namira (putih 155 B) dan Ayesha (putih 155 C). Begitu pula dengan genotipe dengan mahkota bunga berwarna ungu memiliki tipe warna ungu yang berbeda dengan Lembayung (unguviolet N82 A), dengan bagian tepi berwarna violet $83 \mathrm{~A}$.

Mahkota bunga semua genotipe apabila diamati secara langsung berwarna seperti warna hijau. Warna hijau masing-masing genotipe tersebut dideskripsikan lebih jelas dengan RHS Color Chart menjadi warna hijau keabu-abuan, hijau keunguan, hijau keputihan, dan lain-lain (Tabel 6). Kedudukan bunga semua genotipe dan varietas pembanding adalah menghadap ke atas, kecuali genotipe F5 Syakira X 320-202-2-2 yang kedudukan bunganya adalah ke bawah sesuai dengan buahnya yang juga menggantung kebawah.

Daun genotipe Violeta dan Nazla berwarna hijau (hijau 137 A) dengan semburat ungu (ungu N186 A). Genotipe uji selain dua genotipe tersebut berdaun hijau (hijau 137 C) sama dengan warna daun semua varietas pembanding. Sebagian besar daun genotipe uji dan verietas pembanding berbentuk oval, kecuali varietas Namira, genotipe F5 Syakira X 320 201-1-1, dan F5 Syakira X 320-202-2-2 yang berdaun lanset dan F5 Syakira X 320-201-1-2 berdaun deltoid (Tabel 7).

Bentuk buah genotipe Violeta, Nazla, F5 Syakira X 320-201-1-1, dan F5 Syakira X 320-202-2-2 sama dengan varietas Namira dan Lembayung yaitu berbentuk memanjang dengan pangkal buah berbentuk lancip.

Tabel 5. Habitus, pemendekan ruas, dan warna batang setiap genotipe

\begin{tabular}{lccc}
\hline \multicolumn{1}{c}{ Genotipe } & Habitus & Pemendekan ruas & Warna batang \\
\hline Ayesha 1 & tegak & tidak ada & hijau \\
Viola-0 & tegak & tidak ada & hijau \\
Violeta & tegak & tidak ada & ungu-hijau \\
Nazla & intermediate & tidak ada & ungu-hijau \\
F5 Syakira X 320-201-1-1 & intermediate & tidak ada & hijau \\
F5 Syakira X 320-201-1-2 & intermediate & tidak ada & hijau \\
F5 Syakira X 320-201-2-1 & tidak ada & hijau \\
F5 Syakira X 320-202-1-1 & intermediate & hijau \\
F5 Syakira X 320-202-2-1 & tidak ada & hijau \\
F5 Syakira X 320-202-2-2 & tidak ada & ungu-hijau \\
F5 Syakira X 320-202-2-3 (Viola) & intermediate & tidak ada & hijau \\
Namira & tegak & tidak ada & hijau \\
Lembayung & intermediate & ada & ungu \\
Ayesha & intermediate & tidak ada & hijau \\
\hline
\end{tabular}

Keterangan: warna batang berdasarkan RHS Color Chart: hijau (hijau 143 C), ungu (ungu N186-A). 
Sedangkan buah varietas Ayesha sama dengan genotipe Ayesha 1, Viola-0, F5 Syakira X 320-201-1-2, F5 Syakira X 320-201-2-1, F5 Syakira X 320-202-1-1, F5 Syakira X 320-202-2-1, dan Viola yaitu berbentuk triangular dengan pangkal buah berbentuk tumpul. Pewarnaan antosianin diamati berdasarkan ada tidaknya antosianin yang ditandai dengan warna ungu pada buku dan buah muda sebelum terjadi perubahan warna (Naktuinbouw, 2010). Varietas Namira dan Ayeha serta genotipe F5 Syakira X 320-2011-1 dan F5 Syakira X 320-201-1-2 tidak ditemukan adanya pewarnaan antosianin.

Perubahan warna buah biasanya terjadi pada setiap tahap pematangan buah mulai dari buah muda, intermediate, sampai buah matang. Pada genotipe Ayesha 1 dan F5 Syakira

Tabel 6. Warna mahkota, warna anter, dan kedudukan bunga setiap genotipe

\begin{tabular}{lcc}
\hline \multicolumn{1}{c}{ Genotipe } & Warna mahkota & Warna anter \\
\hline Ayesha 1 & putih 155 A, ungu 79 C dengan tepi ungu 79 A & ungu keabu-abuan N187 A \\
Viola-0 & ungu-violet N82 C dengan tepi violet 83 A & hijau keabu-abuan 191 A, violet 83 A \\
Violeta & ungu-violet N83 A & hijau N138 C \\
Nazla & violet 83 B & putih 155 A \\
F5 Syakira X 320-201-1-1 & & hijau keabu-abuan 194 B, ungu 79 A \\
& putih NN 155 A & ungu keabu-abuan N178 B, \\
F5 Syakiau keabu-abuan 191 A & hijau N138 C \\
F5 Syakira X 320-201-2-1 & putih 155 A, dengan tepi violet 83 B & hijau keabu-abuan N189 A, ungu 79 B \\
F5 Syakira X 320-202-1-1 & ungu-violet N82 B & violet-biru N92 A \\
F5 Syakira X 320-202-2-1 & violet 86 A & ungu 79 A \\
F5 Syakira X 320-202-2-2 & ungu 79 A, hijau keputihan 157 A & violet-biru N92 A \\
F5 Syakira X 320-202-2-3 (Viola) & putih 155 A, violet 83 A & hijau 138 C, ungu 79 A \\
Namira & putih 155 B & hijau keputihan 157 B, \\
Lembayung & & kuning kehijauan 144 A \\
Ayesha & ungu-violet N82 A dengan tepi violet 83 A & hijau keabu-abuan 191 A, ungu 79 A \\
\hline
\end{tabular}

Keterangan: warna berdasarkan RHS Color Chart.

Tabel 7. Warna daun, bentuk daun, bentuk buah, bentuk pangkal buah, dan pewaarnaan antosianin setiap genotipe

\begin{tabular}{lccc}
\hline \multicolumn{1}{c}{ Genotipe } & Kedudukan bunga & Warna daun & Bentuk daun \\
\hline Ayesha 1 & ke atas & hijau & oval \\
Viola-0 & ke atas & hijau & oval \\
Violeta & ke atas & ungu-hijau & oval \\
Nazla & ke atas & ungu-hijau & oval \\
F5 Syakira X 320-201-1-1 & hijau & lanset \\
F5 Syakira X 320-201-1-2 & ke atas & hijau & deltoid \\
F5 Syakira X 320-201-2-1 & hijau & oval \\
F5 Syakira X 320-202-1-1 & ke atas & oval \\
F5 Syakira X 320-202-2-1 & hijau & oval \\
F5 Syakira X 320-202-2-2 & ke atas & hijau & lanset \\
F5 Syakira X 320-202-2-3 (Viola) & ke atas & hijau & oval \\
Namira & ke bawah & he atas & lanset \\
Lembayung & ke atas & hijau & oval \\
Ayesha & ke atas & hijau & oval
\end{tabular}

Keterangan: Nazla dan Violeta: hijau (hijau 137 A) dan ungu (ungu N186 A), selain Nazla dan Violeta: hijau (hijau 137 C). 
X 320-202-1-1, buah mengalami dua kali perubahan warna yang signifikan saat fase intermediate yaitu muncul warna ungu setelah warna hijau atau kuning sebelum akhirnya berubah menjadi warna oranye dan kemudian berwarna merah saat buah matang. Warna ungu dan hitam pada cabai merupakan ekspresi dari adanya akumulasi antosianin. Warna ungu pada daun yang ditemukan pada beberapa genotipe juga disebabkan oleh jenis antosianin yang sama dengan yang berada pada buah. Antosianin pada buah terakumulasi pada bagian luar mesokarp dan pada daun di bagian sel palisade dan mesofil (Lightbourn et al., 2008).
Antosianin memiliki berbagai fungsi pada tanaman termasuk perlindungan terhadap stres ultraviolet dan stress oksidatif, feeding deterrent, dan penarik polinator. Antosianin juga mempengaruhi preferensi konsumen terhadap kualitas bunga dan buah, potensi kesehatan pangan, dan atribut hortikultura terkait lainnya (Stommel et al., 2009).

\section{Preferensi Konsumen}

Informasi mengenai preferensi konsumen pada percobaan ini dilakukan dengan memberikan kuesioner

Tabel 7. Warna daun, bentuk daun, bentuk buah, bentuk pangkal buah, dan pewaarnaan antosianin setiap genotipe

\begin{tabular}{lccc}
\hline \multicolumn{1}{c}{ Genotipe } & Bentuk buah & Bentuk pangkal buah & Antosianin \\
\hline Ayesha 1 & triangular & tumpul & ada \\
Viola-0 & triangular & tumpul & ada \\
Violeta & memanjang & lancip & ada \\
Nazla & memanjang & lancip & ada \\
F5 Syakira X 320-201-1-1 & memanjang & lancip & tidak ada \\
F5 Syakira X 320-201-1-2 & triangular & tumpul & tidak ada \\
F5 Syakira X 320-201-2-1 & triangular & tumpul & ada \\
F5 Syakira X 320-202-1-1 & triangular & tumpul & ada \\
F5 Syakira X 320-202-2-1 & triangular & tumpul & ada \\
F5 Syakira X 320-202-2-2 & memanjang & lancip & ada \\
F5 Syakira X 320-202-2-3 (Viola) & triangular & tumpul & ada \\
Namira & memanjang & lancip & tidak ada \\
Lembayung & memanjang & lancip & ada \\
Ayesha & triangular & tumpul & tidak ada \\
\hline
\end{tabular}

Tabel 9. Perubahan warna buah dari buah muda sampai matang

\begin{tabular}{|c|c|c|c|}
\hline \multirow{2}{*}{ Genotipe } & \multicolumn{3}{|c|}{ Perubahan warna buah } \\
\hline & Muda & Intermediate & Matang \\
\hline Ayesha 1 & hijau NN137 B & hitam 203 B, kuning-hijau N144 A & oranye N25 A,merah N45 \\
\hline Viola-0 & ungu N79 B & oranye N25 A & merah $42 \mathrm{~A}$ \\
\hline Violeta & hitam $202 \mathrm{~A}$ & oranye N25 A & merah N45 A \\
\hline Nazla & hitam 203 B & kuning-hijau $146 \mathrm{~A}$ & oranye-merah N34 A \\
\hline F5 Syakira X 320-201-1-1 & kuning $3 \mathrm{D}$ & oranye N25 A & \\
\hline F5 Syakira X 320-201-1-2 & kuning $3 \mathrm{~B}$ & oranye N25 B & merah $44 \mathrm{~A}$ \\
\hline F5 Syakira X 320-201-2-1 & kuning-hijau $150 \mathrm{C}$ & ungu N79 A & oranye-merah N30 A \\
\hline F5 Syakira X 320-202-1-1 & kuning $3 \mathrm{~B}$ & ungu N79 A, oranye-merah N30 D & merah $42 \mathrm{~A}$ \\
\hline F5 Syakira X 320-202-2-1 & kuning-hijau N144 B & ungu keabu-abuan N186 A & merah $45 \mathrm{~B}$ \\
\hline F5 Syakira X 320-202-2-2 & kuning-hijau N144 A & ungu N77 A & merah $45 \mathrm{~A}$ \\
\hline $\begin{array}{l}\text { F5 Syakira X 320-202-2-3 } \\
\text { (viola) }\end{array}$ & ungu N79 A & oranye N25 A & merah $42 \mathrm{~A}$ \\
\hline Namira & kuning-hijau $154 \mathrm{C}$ & oranye N25 A & merah $42 \mathrm{~A}$ \\
\hline Lembayung & ungu N79 A & oranye N25 A & merah $42 \mathrm{~A}$ \\
\hline Ayesha & kuning-hijau $150 \mathrm{C}$ & oranye N25 A & oranye-merah N30A \\
\hline
\end{tabular}


pada 25 partisipan untuk memilih genotipe yang paling disukai. Partisipan memilih berdasarkan karakter seperti perawakan tanaman, warna buah, dan bentuk buah. Karakter tanaman cabai hias yang lebih disukai adalah yang memiliki perawakan pendek, warna buah beragam, dan bentuk buah membulat. Genotipe yang paling disukai adalah Ayesha 1, Violeta, dan Nazla. Ayesha 1 disukai karena bentuk buahnya yang agak membulat dan warna buahnya yang menarik dan cukup beragam. Violeta dan Nazla disukai karena buahnya berwarna ungu. Partisipan juga menyukai perawakan Nazla yang pendek karena lebih cocok untuk tanaman hias pot dan memudahkan perawatannya. Menurut Putra et al. (2017), konsumen menyukai cabai hias berdasarkan bentuk dan warna buah yaitu tanaman yang memiliki proporsi yang bagus dan warna buah yang beragam.

\section{KESIMPULAN}

Semua genotipe yang dievalusi memiliki karakter kuantitatif dan kualitatif yang beragam baik antar genotipe uji maupun dengan varietas pembanding, terutama pada karakter bobot buah, panjang buah, dan warna buah. Berdasarkan uji preferensi konsumen yang dilakukan dengan kuesioner, Genotipe yang paling disukai adalah Ayesha 1, Violeta, dan Nazla. Ayesha 1 disukai karena bentuk buahnya yang agak membulat dan warna buahnya yang menarik dan cukup beragam. Violeta dan Nazla disukai karena buahnya berwarna ungu. Partisipan juga menyukai perawakan Nazla yang pendek karena lebih cocok untuk tanaman hias pot dan memudahkan perawatannya.

\section{UCAPAN TERIMA KASIH}

Terima kasih disampaikan kepada Kementerian Ristekdikti yang telah membiayai penelitian ini melalui hibah PTUPT tahun 2018

\section{DAFTAR PUSTAKA}

Ari, E., H. Bedir, H. Yildrim, T. Yildrim. 2016. Andogenic responses of 64 ornamental pepper (Capsicum annuит L.) genotypes to shed-microspore culture in the autumn season. Turk J Biol. 40:706-717.

Harpenas, A., R. Dermawan. 2010. Budidaya Cabai Unggul. Penebar Swadaya, Jakarta, ID.

[IPGRI] International Plant Genetic Resources Institute. 1995. Descriptors for Capsicum (Capsicum spp.). International Plant Genetic Resources Institute, Roma, IT.

Lannes, S.D., F.L. Finger, A.R. Schuelter, V.W.D Sasali. 2007. Growth and quality of Brazilian accessions of Capsicum chinense fruits. Scientia Horticulturae 112: 266-270.
Lestari, R. 2017. Evaluasi karakter kualitatif dan kuantitatif galur-galur cabai hias (Capsicum annuum L.) IPB untuk tanaman pot. Skripsi. Institut Pertanian Bogor. Bogor.

Lightbourn, G.J., R.J. Griesbach, J.A. Novotny, B.A. Clevidence, D.D. Rao, J.R. Stommel. 2008. Effects of anthocyanin and carotenoid combinations on foliage and immature fruit color of Capsicum annuum L. Journal of Heredity 99(2):105-111.

Naktuinbouw. 2010. Calibration Books Capsicum annuum L, Sweet Pepper, Hot Pepper, Paprika, Chili. Version 1. Variety Testing Department, The Nederlands, NL.

Putra, B.A, K. Suketi, M. Syukur. 2017. Growth and development of ornamental chilli (Capsicum annuum L.) with different types of fertilizer and growing media. Journal of tropical crop science 4(2): 41-48.

Rommahdi, M., A. Soegianto, N. Basuki. 2015. Keragaman fenotipik generasi F2 empat cabai hibrida pada lahan organik (Capsicum annuum L.). Jurnal Produksi Tanaman 3(4): 259-268.

Santos Pessoa, A.M.D., E.R.D. Rêgo, M.G.D. Carvalho, C.A.P.D. Santos, M.M.D Rêgo. 2018. Genetic diversity among accessions of Capsicum annuum L. through morphoagronomic characters. Genetics and Molecular Research 17(1): 1-15.

Setiadi. 2011. Bertanam Cabai di Lahan dan Pot. Penebar Swadaya, Jakarta, ID.

Silva, C.Q., J.M. Jasmin, J.O. Santos, C.S. Bento, C.P. Sudré, R. Rodrigues. 2015. Phenotyping and selecting parents for ornamental purposes in pepper accessions. Horticultura Brasileira 33: 066-073.

Stommel, J.R., G.J. Lightbourn, B.S. Winkel Robert, R.J. Griesbach. 2009. Transcription factor families regulate the anthocyanin biosynthetic pathway in Capsicum annuum. J. Amer. Soc. Hort. Sci. 134(2):244-251.

Sulassih, M. Syukur, Sobir, A. Maharijaya, A. Hakim, Ratih. 2017. Karakterisasi lima galur cabai hias dalam rangka pendaftaran varietas hasil pemuliaan. Comm. Hort. J. 1(1):26-33.

Syukur, M., S. Sujiprihati, R. Yunianti, K. Nida. 2010. Pendugaan komponen ragam, heritabilitas, dan korelasi untuk menentukan kriteria seleksi cabai (Capsicum annuum L.) populasi F5. J. Hort. Indonesia $1(2): 74-80$ 